\title{
REMODULATING EFFECT OF DOXORUBICIN ON THE STATE OF IRON-CONTAINING PROTEINS, AND REDOX CHARACTERISTICS OF TUMOR WITH ALLOWANCE FOR ITS SENSITIVITY TO CYTOSTATIC AGENTS
}

\author{
V. F. CHEKHUN, Yu. V. LOZOVSKA, A. P. BURLAKA, \\ I. I. GANUSEVICH, Yu. V. SHVETS, N. Yu. LUKYANOVA, \\ I. M. TODOR, N. A. TREGUBOVA, L. A. NALESKINA \\ R. E. Kavetsky Institute of Experimental Pathology, Oncology \\ and Radiobiology, National Academy of Sciences of Ukraine, Kyiv; \\ e-mail: Lozovskaya.2012@mail.ru
}

The study was aimed at determining the changes of metal-containing proteins in blood serum and tumor tissue of animals with parental and doxorubicin-resistant strains of Walker-256 carcinosarcoma before and after the cytostatic administration. It has been shown that upon doxorubicin action the levels of total iron and transferrin in the tissues from the both groups of animals decreased while that of ferritine simultaneously increased with more pronounced pattern in the group of animals with resistant tumor strain. It has been shown that upon the action of doxorubicin in tumor tissue of animals with different sensitivity to the cytostatic there could be observed oppositely directed changes in the redox state of these cells that in turn determined the content of "free iron" complexes, ROS generation and concentration of active forms of matrix metaloproteinase-2 and matrix metaloproteinase-9, namely, the increase of these indexes in animals with parental strain and their decrease in animals with the resistant one. So, our study has demonstrated the remodulating effect of doxorubicin on the state of metal-containing proteins and redox characteristics of tumor dependent on its sensitivity to cytostatic, at the levels of the tumor and an organism. These data may serve as a criterion for the development of programs for the correction of malfunction of iron metabolism aimed at elevating tumor sensitivity to cytostatic agents.

K e y words: Walker-256 carcinosarcoma, ferritin, trasnferrin, ceruloplasmin, "free iron" complexes, total iron, reactive oxygen species, matrix metaloproteinase-2 and matrix metaloproteinase-9, doxorubicin.

$\mathrm{T}$ he hypothesis by Academician M. M. Emanuel remains urgent at the present stage of development of oncologic science. It is based on free-radical nature of the processes set going in carcinogenesis and is considered that starting mechanism which leads to disturbances of functional activity of numerous systems-regulators of the energy, lipid, nucleoprotein metabolisms both in the tumor focus and at the level of organism [1-3].

It has been proved by numerous investigations that availability of malignantly transformed cells in an organism initiates the disturbances in metabolism of iron and metal-containing proteins [4-7]. Data exist that changes in iron metabolism appear at the early stages of malignant transformation and are enhanced in the process of forming more aggressive phenotype by cells. It has been established that the tumor creates a pool of decompartmentalized, reactive "free iron" $\left(\mathrm{Fe}^{2+}\right)$ possessing prooxidant properties by accumulating proteins attracted to iron depositing and transportation, that is ferritin (FR) and transferrin (Tr), as well as at the expense of decreasing its removal through ferroportin [8-11]. In turn, superoxide radicals affect, both directly and indirectly, the regulation of activity of matrix proteinases and activation of the processes of peroxide oxidation of lipids (POL) that results in degradation of the intercell matrix and desruption of membrane integrity. At the same time it is generally known that the basic amount of iron in biological samples is transferred and deposited in the organism as a component of various iron-containing complexes in the form of trivalent iron and does not practically occur in the form of free cations. It is known that this 
essential element is bound to protein-transporter $\mathrm{Tr}$ and deposited in FR. Data from literature and results of our research evidence that FR besides its main function performs the antioxidant protection in the process of accumulation of free-radical compounds in a cell [11-13]. Separate reports exist that doxorubicin action leads to the change of cytosol and mitochondrial homeostasis of iron that results in the increase of expression of mitochondrial FR both in the tumor cells and in unmalignized tissues [14-16]. The above changes lead to this protein involvement in the system of antioxidant protection of cells from doxorubicin-induced toxicity. Thus, an important part in iron homeostasis in the organism is assigned to FR $[17,18]$.

Besides, it has been established that metalcontaining proteins, which take part in regulation of endogenous iron, are also used in the mechanisms of forming resistance to antitumor drugs [19, 20]. It has been shown that in the tumor cells resistant both to cysplatin and doxorubicin one can observe changes in the levels of proteins-regulators of metabolism of endogenous iron (transferrin receptor, transferrin, light and hard chains of ferritin, ferroportin and hepsidin). The above data give every reason to think that the disturbance in iron metabolism at the level of methylation of genes-regulators of iron metabolism is one of the factors of development of drug resistance to various, as to action mechanism, antitumor medicines [19, 21]. However there is practically no information in modern literature concerning changes in the content of metal-containing proteins in tumor bearers' organism under the effect of antitumor medicines, especially in those insensitive to cytostatics.

That is why the estimation and analysis of the state of metal-containing proteins in the system under the effect of cytostatics may allow one to reveal new promising targets for overcoming resistance to drugs and to favor individualization of therapeutic patterns.

Our work was aimed at the investigation of changes in the content of metal-containing proteins: transferrin, ferritin and matrix metalloproteinases-2 (MMP-2) and matrix metalloproteinases-9 (MMP-9) in the blood serum and tumor tissue of animals with different sensitivity to doxorubicin under the effect of this cytostatic with allowance for redox-dependent characteristics of a malignant neoplasm.

\section{Materials and Methods}

Female mongrel rats with body weight 150$200 \mathrm{~g}$ taken from the vivarium of R. E. Kavetsky IEPOR, NAS of Ukraine (Kyiv) have been used in the experiment. Animals were kept in standard conditions. All the investigations were performed in accordance with the standards of the Law of Ukraine on Protection of Animals from Cruelty and requirements of European convention on protection of vertebrate animals (Strasbourg, 1986).

The investigation was performed in vivo on the animals with Walker-256 carcinosarcoma with induced resistance to doxorubicin. To obtain the tumor phenotype resistant to the action of doxorubicin the experimental animals were treated by 12 courses of chemotherapy with this drug following the presented scheme. Walker-256 carcinosarcoma was reinoculated into twenty female rats with their further division into the control and therapeutic (experimental) I groups. Doxorubicin in a dose $1.5 \mathrm{mg} /$ $\mathrm{kg}$ of the body weight was administered to the rats of the therapeutic group 4 days after tumor reinoculation. A course of the cytostatic injections proceeded for 5 days. The anti-tumor effect according to the carcimoarcoma volume was determined in the therapeutic group I compared with the control one two days after the last injection. After the first course of the therapy the Walker-256 carcinosarcoma growth was inhibited by $65 \pm 5 \%$. The next stage of resistance development was the extraction of tumor from the animals of therapeutic group I, preparation of suspension of this tumor for further reinoculation into female rats. Animals of this group were also treated with a course of chemotherapy following the scheme. The anti-tumor effect of antibiotic was determined after 4, 8 and 12 courses of therapy (therapeutic group II). The performing of 4 courses of chemotherapy resulted in the tumor growth inhibition by $30.0 \pm 2.7 \%$, 8 courses - by $9.0 \pm 1.4 \%$, and after 12 courses by $0 \%$, i. e., in this case the tumor growth was not practically inhibited by the antibiotic. The results of each stage of resistance formation just after 4, 8 and 12 courses of doxorubicin injection were compared with the data obtained in the animals which were not treated with the drug (0 courses). In the process of each course of chemotherapy Walker-256 carcinosarcoma was reinoculated into a group of animals which were never treated with doxorubicin. The number of reinoculations of 
the initial tumor and that in the process of resistance formation was the same.

Animals with both sensitive and resistant tumors were treated with therapeutic course of doxorubicin in a dose of $15 \mathrm{mg} / \mathrm{kg}$ (5 injections, total dose $7.5 \mathrm{mg} / \mathrm{kg}$ ), beginning from the $9^{\text {th }}$ day of the tumor reinoculation.

All animals were removed from the experiment by decapitation after sedasin injection (Pulava, Poland).

The content of $\mathrm{Tr}$, "free iron" complexes was determined in the serum and tumor tissue of animals with Walker-256 carcinosarcoma using the method of electron paramagnetic resonance (EPR) by computerized spectrometer R-1307 (Russia) at liquid nitrogen temperature $77 \mathrm{~K}$ [3]. Trilon B was used as anticoagulant. For this purpose $0.25 \mathrm{ml}$ of serum or whole blood was frozen in special pressforms in liquid nitrogen. The EPR spectrum for $\mathrm{Tr}$ was $g=4.25$. The level of active Tr forms was determined by the intensity of EPR spectra of this protein. To determine Tr content in the tumor tissue $0.5 \mathrm{~g}$ of the tissue was placed in special press-forms and frozen in liquid nitrogen.

Besides, the EPR method was used to record a signal of "free iron" complexes which increase leads to the disturbance of membranes, destruction of iron-containing proteins $[7,12,13]$. The signal spectrum of "free iron" complexes was $g=2.2$. Indices of $\operatorname{Tr}$ and "free iron" complex signals were expressed in relative units (rel. un.) in accordance with the inner EPR standard.

Biochemical determination of the content of total iron in the blood serum and tumor tissue was performed using reagents (Total iron, USA), and immunoenzyme analysis (IEA) in the same tissues to estimate FR content it was performed using the reagents (Uscer, China). These indices were estimated by means of automatic biochemical and immunoenzyme analyzer Chem Well 2900 (USA).

The blood serum samples for IEA were obtained due to recommendations given in the instructions for the sets, tumor cell supernatant was prepared in physiological solution with the ratio 1/3. All the samples were centrifuged at $1000 \mathrm{~g}$ during 15 min and kept at $-20{ }^{\circ} \mathrm{C}$.

Investigation of generation of active oxygen forms (AOF) that is: $\mathrm{H}_{2} \mathrm{O}_{2}, \mathrm{NO}, \mathrm{O}_{2}^{-}$, ONOO$\mathrm{HOCl}$ and $\mathrm{OH}^{-}$in the tumor tissue of animals with Walker-256 carcinosarcoma was conduced by flow cytofluorimeter Beckman Coulter EPICS ${ }^{\circledR}$ XL Flow
(Germany) with the use of enzymatic method for obtaining isolated cells. To do this the tumor tissue without necrosis indications was cut-up with scissors and incubated in physiological solution in the presence of type IV colagenase (100 units/ml; Sigma) at $37^{\circ} \mathrm{C}$ during $15 \mathrm{~min}$. The cell suspension was then centrifuged and let through the nylon filter with pore diameter $100 \mu \mathrm{m}$ [22]. Determination of the AOF generation level in cells is based on the use of a specific dye CM-H2DCFDA (Germany) which interacts with the above compounds, with further analysis of the data by the method of flow cytofluorimetry [23].

Concentration of active forms of matrix metalloproteinases MMP-2 and -9 was determined in the blood serum and tumor tissue samples of the studied animals by the method of zymography in polyacrylamide gel (adding gelatin as a substrate) on the basis of SDS-electrophoresis of proteins. After gel washing-off the active forms of MMP-2 and MMP-9 were visualized in a form of decolorized strips on blue background; their localization was determined by the standards of molecular weight and corresponded to molecular weight of each enzyme (72 and $92 \mathrm{kDa}$, respectively). Proteolytic activity was determined by the lysis zone area measuring, using a standard set of MMP-2 and MMP-9 (Sigma, USA). Results were assessed with the help of the standard program TotalLab 1.01 [24].

Statistical processing was made with the use of the software Statistica 6.0 using a batch of programs MS Excel 2010. Density plots of AFK distribution were analyzed using the program for cytometry data processing FCS Express V3, ModFit V3.2. Probability of difference between the indices of various groups was evaluated with the help of Student's $t$ criterion. Correlation coefficient was calculated according to Pearson. Differences were considered reliable at $P<0.05$.

\section{Results and Discussion}

The major research idea was to determine quantitative changes of metal-containing proteins set going in iron metabolism at the tumor and organism level in animals with Walker-256 carcinosarcoma with different sensitivity to doxorubicin as a result of therapeutic effect of this cytostatic with allowance for redox-dependent indices of the tumor tissue. First of all, it was shown that the initial content of "free iron" in carcinosarcoma cells was inconsiderable in the animals with the tumor sensitive to doxorubicin (Table 1). 
Ta ble 1. Quantitative changes of metal-containing proteins and redox-dependent indices in the tumor tissue and blood serum of animals with sensitive Walker-256 carcinosarcoma before and after therapeutic action of doxorubicin

\begin{tabular}{|c|c|c|c|c|}
\hline \multirow{3}{*}{$\begin{array}{l}\text { Redox-dependent indices } \\
\text { and content of iron- } \\
\text { containing proteins }\end{array}$} & \multicolumn{4}{|c|}{ Sensitive tumor } \\
\hline & \multicolumn{2}{|c|}{ Before action } & \multicolumn{2}{|c|}{ After action } \\
\hline & tumor & serum & tumor & serum \\
\hline Compl. of “free iron”, relat. un. & $0.17 \pm 0.09$ & - & $0.21 \pm 0.15$ & - \\
\hline AOF, relat. un. & $5.20 \pm 0.17$ & - & $75.34 \pm 4.52 *$ & - \\
\hline MMP-2, $\mu \mathrm{g} / \mathrm{g}, \mathrm{ng} / \mathrm{ml}$ & $2.4 \pm 0.8$ & $45.0 \pm 8.9$ & $3.5 \pm 0.9$ & $65.1 \pm 6.8$ \\
\hline MMP-9, $\mu \mathrm{g} / \mathrm{g}, \mathrm{ng} / \mathrm{ml}$ & $3.9 \pm 0.8$ & $128.0 \pm 30.1$ & $5.1 \pm 0.9$ & $152.0 \pm 19.1$ \\
\hline Ferritin, ng/ml & $6.0 \pm 0.1$ & $28.62 \pm 2.02$ & $37.84 \pm 5.0 *$ & $4.65 \pm 1.16^{*}$ \\
\hline Total iron, mmol/l & $58.23 \pm 2.10$ & $38.16 \pm 1.18$ & $42.17 \pm 2.10 *$ & $16.16 \pm 2.14^{*}$ \\
\hline Transferrin, relat. un. & $0.39 \pm 0.15$ & $0.48 \pm 0.16$ & $0.28 \pm 0.12$ & $0.31 \pm 0.17$ \\
\hline
\end{tabular}

Note: $* P<0.05$ reliable changes relative to control values (before treatment), $n=10$.

Inconsiderable tendency to a decrease of the content of decompartmentalized iron in sensitive (initial) tumors of studied animals was marked after doxorubicin action. It was also noted that a 15-fold synergic increase of AOF generation was observed in the animal tumor cell after the cytostatic effect. Such a regularity is just acceptable since $\mathrm{Fe}^{2+}$ ions are some key ones in initiation of free-radical compounds.

Concentration of active MMP-2 in the blood serum of animals with sensitive tumors after doxorubicin administration increases almost 1.5 times $(P<0.05)$ compared with this index in animals without therapeutic effect of the cytostatic that, with allowance for the increase of AOF generation level in tumor tissue after the cytostatic effect, may be determined by redox-regulated activation of the latent form of MMP-2 accompanying formation of the tumor oxide phenotype $[4,7,8,12]$.

At the same time, in the tumor tissue and blood serum of studied animals we have analyzed changes (as a result of cytostatic effect) in the content of metal-containing proteins FR and Tr connected with total iron metabolism. It should be mentioned that the notion of "total iron" is a conditional one, since this index permits estimating the level of iron bound to high-molecular proteins, such as FR and Tr. It is known that each Tr molecule can bind two $\mathrm{Fe}^{3+}$ ions and, respectively, gives an idea of the level of transported iron in the organism [5, 10, 13]. It is shown that the level of total iron in the animal blood serum and cells of carcinosarcoma sensitive to doxorubicin reliably decreased 2.36 and 1.38 times, respectively.
Simultaneously, the decrease of $\operatorname{Tr}$ content both in the tumor tissue and blood serum of these animals is not reliable.

Another character of changes has been revealed as to FR content in the tumor tissue and blood serum after the cytostatic action. Thus, the level of this iron-containing protein increased 6.3 times in carcinosarcoma cells, while in the blood serum it decreased 6.1 times. Different direction of this index changes may be explained by the fact that doxorubicin in the cells of peripheral blood can form complexes with iron and accumulate in FR with its gradual degradation and release from the cells $[5,11-13]$.

Similarly, we have analyzed changes of the above indices in animals with resistant Walker-256 carcinosarcoma before and after doxorubicin action. It should be noticed that the content of iron or iron-containing proteins before the cytostatic use both in the tumor tissue and blood serum of this group animals was considerably higher than in the animals with sensitive tumor phenotype (Table 2). After doxorubicin administration to animals with resistant tumor the number of "free iron" complexes decreased 1.6 times in respect of the values obtained before the therapeutic action of the cytostatic. These differences evidence for synergism of iron homeostasis disturbances in the tumor bearer's organism and involvement of this essential cell element in molecular mechanisms of resistance formation

A considerable decrease in concentrations of active gelatinase forms occurred both in the tumor tissue and blood serum of animals under doxorubicin 
Ta ble 2. Quantitative changes of metal-containing indices in tumor tissue and blood serum of animals with resistant Walker-256 carcinosarcoma before and after the therapeutic action of doxorubicin

\begin{tabular}{|c|c|c|c|c|}
\hline \multirow{3}{*}{$\begin{array}{l}\text { Redox-dependent indices } \\
\text { and content of iron- } \\
\text { containing proteins }\end{array}$} & \multicolumn{4}{|c|}{ Resistant tumor } \\
\hline & \multicolumn{2}{|c|}{ Before action } & \multicolumn{2}{|c|}{ After action } \\
\hline & tumor & serum & tumor & serum \\
\hline Compl. of “free iron”, relat. un. & $0.70 \pm 0.14$ & - & $0.44 \pm 0.15^{*}$ & - \\
\hline AOF, relat. un. & $258.55 \pm 68.7$ & - & $180.45 \pm 40.00$ & - \\
\hline MMP-2, $\mu \mathrm{g} / \mathrm{g}, \mathrm{ng} / \mathrm{ml}$ & $30.7 \pm 8.7$ & $210.05 \pm 20.10$ & $6.7 \pm 2.5^{*}$ & $80.05 \pm 20.10^{*}$ \\
\hline MMP-9, $\mu \mathrm{g} / \mathrm{g}, \mathrm{ng} / \mathrm{ml}$ & $34.4 \pm 4.4$ & $650.9 \pm 204.1$ & $2.9 \pm 0.8^{*}$ & $120.9 \pm 30.4^{*}$ \\
\hline Ferritin, ng/ml & $390.1 \pm 17.0$ & $56.9 \pm 3.1$ & $540.30 \pm 19.05^{*}$ & $92.05 \pm 7.74^{*}$ \\
\hline Total iron, mmol/l & $45.73 \pm 7.00$ & $28.75 \pm 4.73$ & $25.85 \pm 4.65^{*}$ & $25.93 \pm 5.03$ \\
\hline Transferrin, relat. un. & $0.96 \pm 0.09$ & $0.76 \pm 0.18$ & $0.49 \pm 0.09 *$ & $0.65 \pm 0.11$ \\
\hline
\end{tabular}

Note: $* P<0.05$ probable changes relative to control values (before treatment), $n=10$.

effect (Table 2). MMP-2 and MMP-9 activity in the tumor tissue decreased 4.6 and 11.84 times, while in the serum - 2.6 and 5.4 times, respectively.

Besides, a probable decrease of the level of total iron (1.7 times) occurred in the resistant tumors under doxorubicin effect, while no essential changes of this index were noted in the blood serum (Table 2). A considerable decrease of $\operatorname{Tr}$ content was noted in the tumor tissue on the background of a decrease of the level of free iron and total iron complexes, that proves once more the synergism of interaction between $\operatorname{Tr}$ and total iron bound to it.

FR content in the tumor tissue of animals with the resistant phenotype before and after doxorubicin action changed in another way. Thus, the level of this iron-containing protein before the doxorubicin action in carcinosarcoma tissue exceeded the values in the initial tumor 65 times, and in the serum - 2 times. After doxorubicin administration to animals with resistant tumors the FR level increased 1.4 and 1.6 times, respectively (Table 2). The value of elevation of the content of this iron-containing protein in the cells of non-sensitive carcinosarcoma under the cytostatic effect on the background of simultaneous decrease of iron with different reactivity in them is rather contradictory.

For more exact interpretation of the data obtained we have analyzed the determined coefficients of correlations among all the studied indices in the tumor tissue of animals with different sensitivity to doxorubicin (Fig. 1 and Fig. 2).

As is evident from Fig. 1, $A, B$, the direct high level correlation is observed between concentrations of active forms of MMP-2 and -9, and the number of "free iron" complexes and AOF generation in the tumor tissue of animals with sensitive and resistant carcinosarcoma before and after doxorubicin administration. The data obtained are rather logic, since the activation of redox-regulated matrix proteinases MMP-2 and -9 depends on the AOF generation level. It is known that one of the ways of their induction is the initiation of Fenton reaction, owing to the increasing number of "free iron" complexes. Following this mechanism the iron ions lead to formation of hydroxyl radicals which also intensify oxidation processes [3, 6]. Our own investigations have shown that the average degree of inverse correlation dependence between the content of Tr and "free iron" complexes is observed in the cells of sensitive carcinosarcoma after the cytostatic action (Fig. 1, A). Another character of changes was determined between the content of FR and the number of "free iron" complexes in the resistant tumor tissue after therapeutic action of doxorubicin , that is: the increase of FR content took place on the background of a decrease of "free iron" complexes (Fig. 1, B).

The correlation dependence between the contents of metalloproteins and total iron (Fig. 2, $A, B$ ) in the tumor tissue has been analyzed in the analogous way. During the comparative research we have noted the high degree of correlation between the contents of FR and Tr and the level of total iron in the tumor tissue of animals with resistant and sensitive carcinosarcoma that is determined by functional properties of these proteins. An inverse correlation between the content of FR and total iron was re- 
A

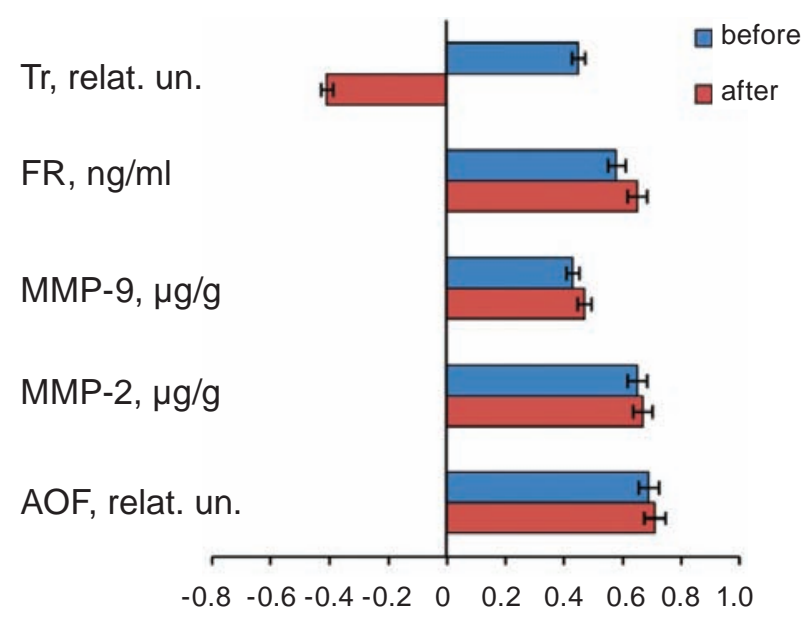

$B$

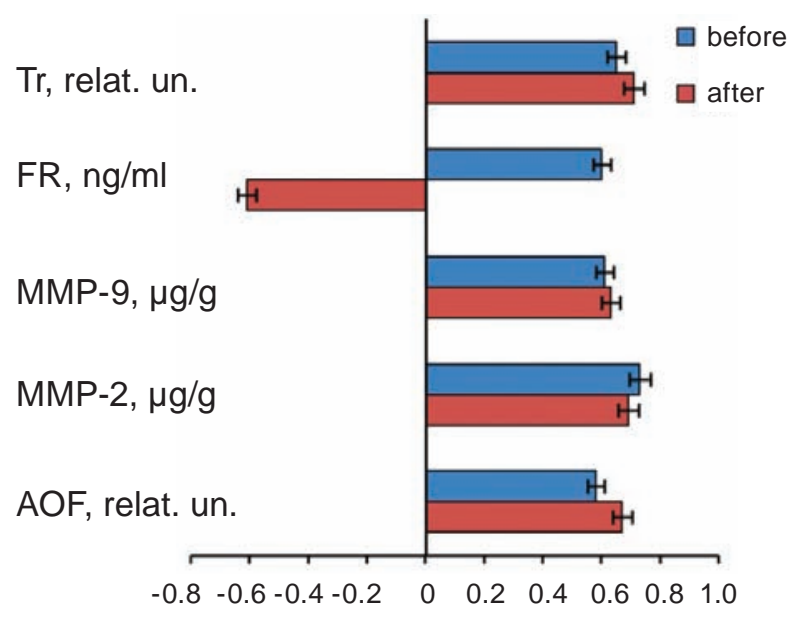

Fig. 1. Coefficients of correlation between indices of "free iron" and level of metal-containing proteins in the tumor tissue of sensitive (A) and resistant (B) Walker-256 carcinosarcoma before and after doxorubicin administration; on the axis of abscissas: correlation coefficient values; on the axis of ordinates: studied indices

vealed after therapeutic action of doxorubicin in the animal tumor tissue independent of its sensitivity to doxorubicin.

A direct average degree of correlation has been established between the total iron content and MMP2 and -9 indices in the animal tumor tissue independent of its sensitivity to the cytostatic both before and after doxorubicin administration (Fig. 2, A, B). Low degree of direct correlation between the total iron content and AOF generation level was determined before and after the cytostatic administration, while in sensitive tumors the correlation coefficient was inverse as well as low (Fig. 2, A, B).

At the same time the correlation has been analyzed between the level of total iron and state of metal-containing proteins:MMP-2 and -9, FR and $\mathrm{Tr}$ in the blood serum of animals of the both studied groups before and after the therapeutic action of the
A

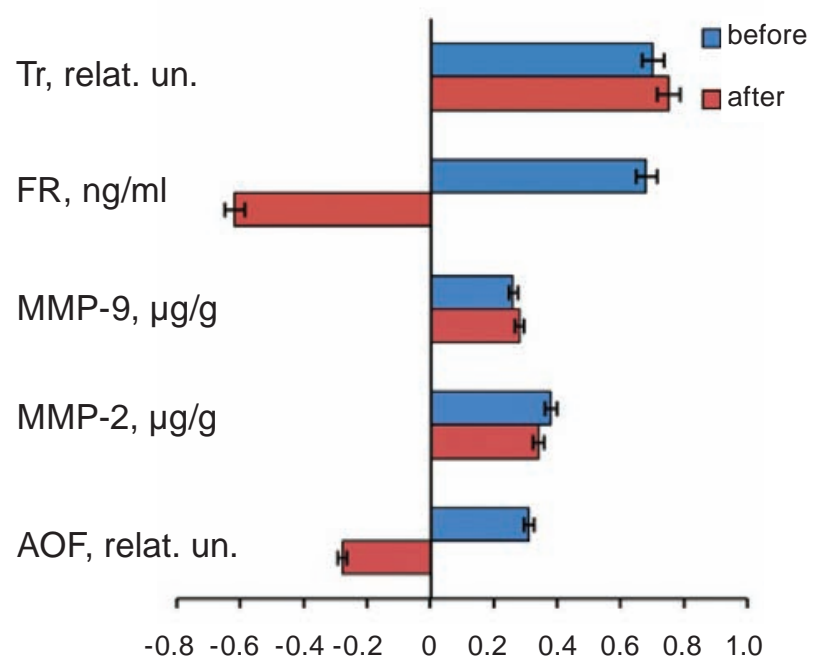

$B$

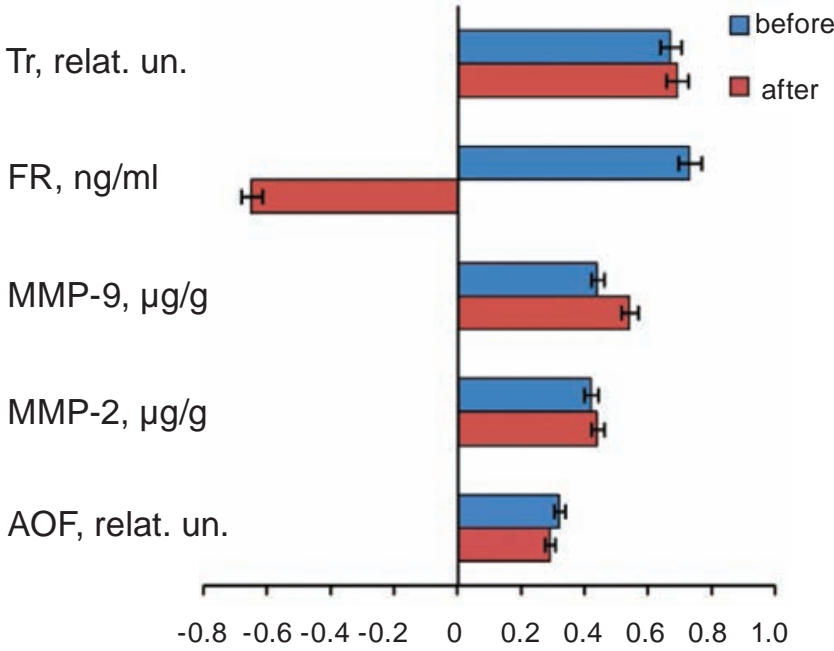

Fig. 2. Coefficients of correlation between the indices of total iron and the level of metal-containing proteins in tumor tissue sensitive (A) and resistant (B) Walker-256 carcinosarcoma before and after doxorubicin administration; on the axis of abscissas: correlation coefficient values; on the axis of ordinates: studied indices 
cytistatic (Fig. 3, A, B). The stress is made just on the total iron indices in the blood serum, since more reactive "free iron" is not stable in the peripheral blood, and is immediately involved in numerous metabolic processes. A high degree of correlation is established between the content of the total iron and FR and Tr in the blood serum of animals with different sensitivity to doxorubicin both before and after the cytostatic administration, however the direction of relation between the content of the total iron and FR after the therapeutic action of the antitumor drug in the serum of resistant animals was of subtraction character (Fig. 3, $A, B$ ).

Low level of correlation between the content of the total iron and indices of MMP-2 and -9 was revealed in the blood serum of animals of the both studied groups before and after doxorubicin administration (Fig. 3, A, B).

Summing up the above stated, one can assert that all the changes in the indices of FR and Tr content, concentration of active gelatinase forms in the studied samples of the serum and tumor tissue of animals with resistant carcinosarcoma after doxorubicin action are interrelated with the content of both "free" and total iron in these tissues. A considerable increase of FR content was observed on the background of a probable decrease of the level of total iron, "free" iron complexes after doxorubicin action in the tumor tissue and blood serum of animals with resistant tumors. The data obtained do not contra- dict the research results of other authors, since there is information that after the long-term influence of doxorubicin in cells on the background of free iron overload researchers revealed the dissociation of the complex IRE/IRP mRNA FR and, as a result, an increase of FR synthesis [25-27].

Attention should be given not only to the increase of FR content but also to the change of redox-dependent indices: MMP-2 and MMP-9 in the blood serum and tumor tissue of animals with resistant carcinosarcoma after doxorubicin action that may evidence for the establishing of a new level of interactions among all the studied indices.

Thus, it has been proved that a parallel decrease of the level of total iron and Tr takes place on the background of simultaneous increase of FR under the effect of doxorubicin in the tumor tissue of animals with Walker-256 carcinosarcoma sensitive or resistant to this cytostatic. The above decrease is more pronounced in the animals with a resistant tumor. It is shown that under the effect of doxorubicin the opposite changes of redox status are observed in the animal tumor tissue independent of its sensitivity to the cytostatic. This affects the number of "free" iron complexes, AOF generation and concentration of active MMP-2 and MMP-9 forms, i.e., the increase in animals with sensitive carcinosarcoma and decrease in rats with the resistant one. The established phenomenon of considerable growth of FR content in the tumor tissue and blood serum of
$\boldsymbol{A}$

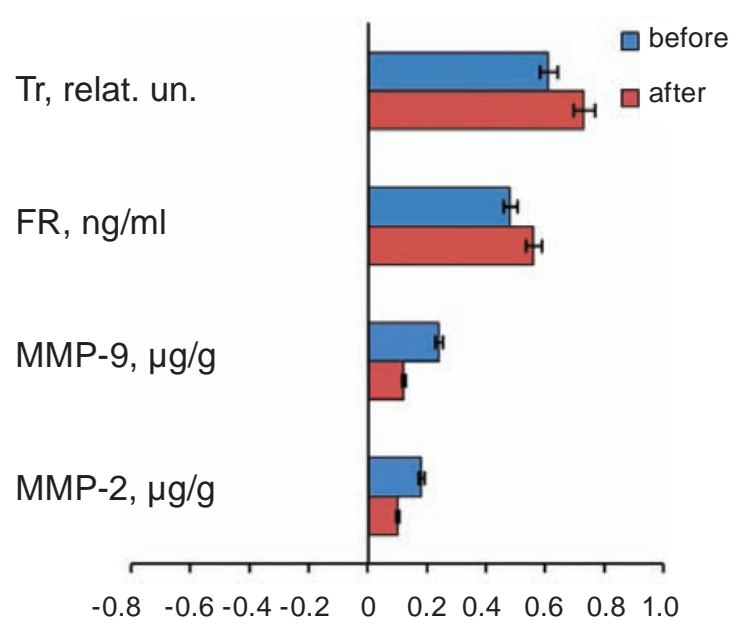

B

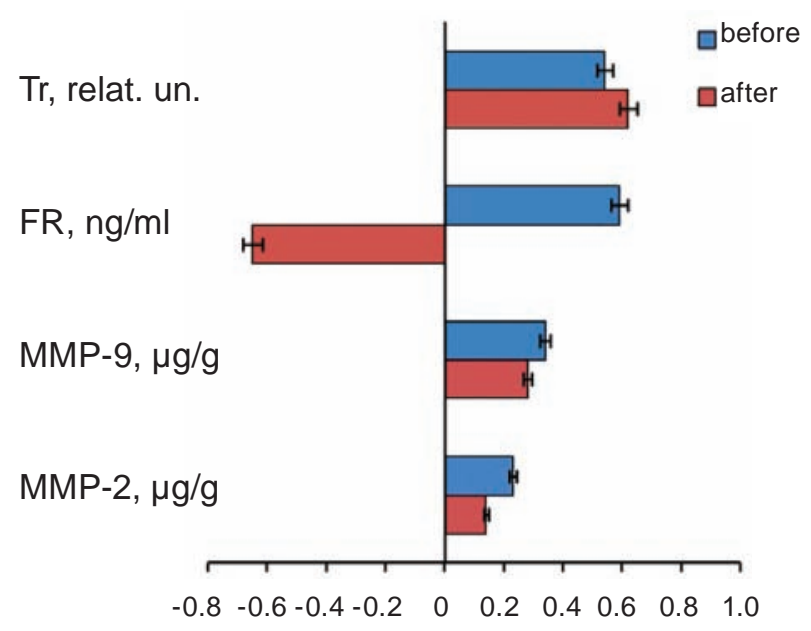

Fig. 3. Coefficients of correlation between the contents of total iron and metal-containing proteins in the blood serum of animals with sensitive (A) and resistant (B) Walker-256 carcinosarcoma before and after doxorubicin action; on the axis of abscissas: correlation coefficient values; on the axis of ordinates: studied indices 
animals with a resistant tumor phenotype after the cytostatic action may be connected with the change of their redox-status and disturbance of this protein RNA functioning. The found remodulating effect of doxorubicin on homeostasis of iron and proteins connected with its metabolism in the tumor bearer's organism with availability of neoplasms with different sensitivity may serve as an experimentally substantiated basis for perfecting the existing and developing new approaches to the increase of tumors' responses, their resistant forms in particular, to therapeutic action of cytostatics.

\section{РЕМОДУЛЮВАЛЬНИЙ ВПЛИВ ДОКСОРУБІЦИНУ НА КІЛЬКІСНІ ПОКАЗНИКИ ЗАЛІЗОВМІСНИХ ПРОТЕЇНІВ ТА РЕДОКСЗАЛЕЖНІ ХАРАКТЕРИСТИКИ ПУХЛИНИ 3 УРАХУВАННЯМ ЇЇ ЧУТЛИВОСТІ ДО ЦИТОСТАТИКА}

\author{
В. Ф. Чехун, Ю. В. Лозовська, А. П. Бурлака, \\ I. І. Ганусевич, Ю. В. Швецьь, \\ Н. Ю. Лук’янова, I. М. Тодор, \\ Н. А. Трегубова, Л. А. Налєскіна
}

Інститут експериментальної патології, онкології і радіобіології ім. Р. Є. Кавецького НАН України, Київ; e-mail: Lozovskaya.2012@mail.ru

Досліджено вміст заліза та залізовмісних протеїнів, а саме феритину і трансферину, в сироватці крові та пухлинній тканині тварин із чутливою та резистентною до доксорубіцину карциносаркомою Уокер-256 до та після дії цитостатика. Встановлено, що в сироватці крові та пухлинній тканині обох груп тварин за дії препарату відбувається паралельне зниження вмісту загального заліза, трансферину на фоні одночасного зростання вмісту феритину, що виявляє вираженіший характер у тварин із резистентними пухлинами. Показано, щоза дії доксорубіцину в пухлинній тканині тварин із різною чутливістю до цитостатика спостерігаються протилежні зміни їнього редокс-статусу, зміною вмісту комплексів «вільного» заліза, генерації АФК та концентрації активних форм матриксних металопротеїназ-2 та -9, а саме - зростання їх у тварин з чутливими пухлинами та зниження - 3 резистентними. Одержані дані можуть слугувати критерієм для розробки програм корекції по- рушень метаболізму заліза з метою підвищення чутливості пухлин до дії цитостатиків.

К л ю ч о в і с лов а: карциносаркома Уокер-256, феритин, трансферин, комплекси «вільного заліза», загальне залізо, активні форми кисню, матриксна металопротеїназа-2 та матриксна металопротеїназа-9, доксорубіцин.

\section{РЕМОДУЛИРУЮЩЕЕ ДЕЙСТВИЕ ДОКСОРУБИЦИНА НА СОДЕРЖАНИЕ ЖЕЛЕЗОСОДЕРЖАЩИХ ПРОТЕИНОВ И РЕДОКСЗАВИСИМЫЕ ХАРАКТЕРИСТИКИ ОПУХОЛИ С УЧЕТОМ ЕЕ ЧУВСТВИТЕЛЬНОСТИ К ЦИТОСТАТИКУ}

\author{
В. Ф. Чехун, Ю. В. Лозовская, А. П. Бурлака, \\ И. И. Ганусевич, Ю. В. Швец, \\ Н. Ю. Лукьянова, И. Н. Тодор, \\ Н. А. Трегубова, Л. А. Налескина
}

Институт экспериментальной патологии, онкологии и радиобиологии
им. P. Е. Кавецкого НАН Украины, Киев;
e-mail: Lozovskaya.2012@mail.ru

Исследовано содержание железа и железосодержащих протеинов, а именно ферритина и трансферрина, в сыворотке и опухолевой ткани животных с чувствительной и резистентной к доксорубицину карциносаркомой Уокер-256 до и после действия цитостатика. Установлено, что в сывортке крови и в опухолевой ткани в обеих группах животных под действием препарата происходит параллельное снижение уровня общего железа, трансферрина на фоне одновременного повышения ферритина, что имеет более выраженный характер у животных с резистентными опухолями. Показано, что под действием доксорубицина в опухолевой ткани животных с различной чувствительностью к цитостатику наблюдается разнонаправленный характер изменений редокс-статуса этих клеток, что подтверждается изменениями количества комплексов «свободного» железа, генерации АФК и концентраций активных форм матриксных металлопротеиназ-2 и -9 , а именно: увеличение их содержания у животных с чувствительными опухолями и снижение - с резистентными. Полученные данные могут служить критерием для разработки программы коррекции нарушений метаболизма железа с целью повышения чув- 
ствительности опухоли к действию противоопухолевых препаратов.

К л ю ч е в ы е с ло в а: карциносаркома Уокер-256, ферритин, трансферрин, комплексы «свободного железа», общее железо, активные формы кислорода, матриксная металлопротеиназа-2 и матриксная металлопротеиназа-9, доксорубицин.

\section{References}

1. Emmanuel N. M. Chain reaction. M.: Nauka, 1989. 328 p. (In Russian).

2. Zhukov V. I., Perepadya S. V., Vinnik Ju. A., Zaytseva O. V., Moiseenko A. S. Oxidizingantioxidizing interaction and structuralfunctional state of plasmatic membranes in patients receiving colorectal cancer. Visnuk Probl. Biol. Med. 2010; 1: 116-120.

3. Burlaka A. P., Sydoryk E. P. Radical oxygen species and nitric oxide in tumor-protsesi. Kyiv: Science. Thought, 2006. 227 p. (In Ukrainian).

4. Beguin Y., Aapro M., Ludwig H., Mizzen L., Osterborg A. Epidemiological and nonclinical studies investigating effects of iron in carcinogenesis - a critical review. Crit. Rev. Oncol. Hematol. 2014; 89(1): 1-15.

5. Prutki M., Poljak-Blazi M., Jakopovic M., Tomas D., Stipancic I., Zarkovic N. Altered iron metabolism, transferrin receptor 1 and ferritin in patients with colon cancer. Cancer Lett. 2006; 238(2): 188-196.

6. Ludwig H., Evstatiev R., Kornek G., Aapro M., Bauernhofer T., Buxhofer-Ausch V., Fridrik M., Geissler D., Geissler K., Gisslinger H., Koller E., Kopetzky G., Lang A., Rumpold H., Steurer M., Kamali H., Link H. Iron metabolism and iron supplementation in cancer patients. Wien. Klin. Wochenschr. 2015; 127(23-24): 907-19.

7. Bystrom L. M., Rivella S. Cancer cells with irons in the fire. Free Radic. Biol. Med. 2015; 79: 337342.

8. Mukaide T., Hattori Y., Misawa N., Funahashi S., Jiang L., Hirayama T., Nagasawa H., Toyokuni S. Histological detection of catalytic ferrous iron with the selective turn-on fluorescent probe RhoNox-1 in a Fenton reaction-based rat renal carcinogenesis model. Free Radic. Res. 2014; 48(9): 990-995.

9. Li J., Zhang D., Jefferson P. A., Ward K. M., Ayene I. S. A bioactive probe for glutathionedependent antioxidant capacity in breast cancer patients: implications in measuring biological effects of arsenic compounds. J. Pharmacol. Toxicol. Methods. 2014; 69(1): 39-48.

10. Gkouvatsos K., Papanikolaou G., Pantopoulos K. Regulation of iron transport and the role of transferrin. Biochim. Biophys. Acta. 2012; 1820(3): 188-202.

11. Kakhlon O., Gruenbaum Y., Cabantchik Z. I. Ferritin expression modulates cell cycle dynamics and cell responsiveness to H-rasinduced growth via expansion of the labile iron pool. Biochem. J. 2002; 363(Pt 3): 431-436.

12. Chekhun V. F., Lozovska Y. V., Burlaka A. P., Lukyanova N. Y., Todor I. N., Naleskina L. A. Peculiarities of antioxidant system and iron metabolism in organism during development of tumor resistance to cisplatin. Exp. Oncol. 2014; 36(3): 196-201.

13. Recalcati S., Minotti G., Cairo G. Iron regulatory proteins: from molecular mechanisms to drug development. Antioxid. Redox Signal. 2010; 13(10): 1593-616.

14. Cocco E., Porrini V., Derosas M., Nardi V., Biasiotto G., Maccarinelli F., Zanella I. Protective effect of mitochondrial ferritin on cytosolic iron dysregulation induced by doxorubicin in HeLa cells. Mol. Biol. Rep. 2013; 40(12): 6757-6764.

15. Pelicano H., Zhang W., Liu J., Hammoudi N., Dai J., Xu R. H., Pusztai L., Huang P. Mitochondrial dysfunction in some triplenegative breast cancer cell lines: role of mTOR pathway and therapeutic potential. Breast Cancer Res. 2014; 16(5): 434.

16. Chen G., Pelicano H., Ogasawara M. A., Wang F., Huang P. Targeting Mitochondria of Cancer Cells: Mechanisms and Compounds. Available at http://link.springer.com/chapt er/10.1007/978-94-017-8984-4_8 (accesed, May, 2014).

17. Elliott R. L., Head J. F. Cancer: Tumor Iron Metabolism, Mitochondrial Dysfunction and Tumor Immunosuppression; "A Tight Partnership-Was Warburg Correct?” J. Cancer Ther. 2012; 3(4): 278-311.

18. Torti S. V., Torti F. M. Iron and cancer: more ore to be mined. Nat. Rev. Cancer. 2013; 13(5): 342-355.

19. Chekhun V., Lukianova N., Demash D., Borikun T., Chekhun S., Shvets Y. Manifestation of key molecular genetics markers in pharmacocorrection of endogenous iron 
metabolism in MCF-7 and MCF-7/DDP human breast cancer. CellBio. 2013; 2(4): 217-227.

20. Yurchenko O. V., Todor I. N., Tryndyak V. P., Tregubova N. A., Kovtonyuk O. V., Solyanik G. I., Kulik G. I., Chekhun V. F. Resistance of Guerin's carcinoma cells to cisplatine: biochemical and morphological aspects. Exp. Oncol. 2003; 25: 64-68.

21. Pogribny I. P., Tryndyak V. P., Pogribna M., Shpyleva S. I., Surratt G., Gamboa da Costa G., Beland F. A. Modulation of intracellular iron metabolism by iron chelation affects chromatin remodeling proteins and corresponding epigenetic modifications in breast cancercells and increases their sensitivity to chemotherapeutic agents. Int. J. Oncol. 2013; 42(5): 1822-1832.

22. Muramatsu S., Tanaka S., Mogushi K., Adikrisna R., Aihara A., Ban D., Ochiai T., Irie T., Kudo A., Nakamura N., Nakayama K., Tanaka H., Yamaoka S., Arii S. Visualization of stem cell features in human hepatocellular carcinoma reveals in vivo significance of tumorhost interaction and clinical course. Hepatology. 2013; 58(1): 218-228.
23. Manna A., Saha P., Sarkar A., Mukhopadhyay D., Bauri A. K., Kumar D., Das P., Chattopadhyay S., Chatterjee M. Malabaricone-A induces a redox imbalance that mediates apoptosis in U937 cell line. PLoS One. 2012; 7(5): e36938.

24. Solovyeva N. I., Ryzhakova O. S. Methods for determining matrix metalloproteinase activity. Klin. Lab. Diagn. 2010; (2): 17-21. (In Russian).

25. Joshi R. S., Morán E., Sánchez M. Cellular iron metabolism-the IRP/IRE regulatory network. Iron metabolism. Available from: http://www. intechopen.com/books/iron-metabolism/ cellular-iron-metabolism-the-irp-ire-regulatorynetwork (accessed. June 2012).

26. Canzoneri J. C., Oyelere A. K. Interaction of anthracyclines with iron responsive element mRNAs. Nucleic Acids Res. 2008; 36(21): 68256834.

27. Pang M. B., Connor J. R. Role of Ferritin in Cancer Biology. J. Cancer Sci. Ther. 2015; 7: 155-160.

Received 01.07.2015 